\title{
Direct radiative effect by brown carbon over the Indo-Gangetic Plain
}

\author{
A. Arola ${ }^{1}$, G. L. Schuster ${ }^{2}$, M. R. A. Pitkänen ${ }^{1,3}$, O. Dubovik ${ }^{4}$, H. Kokkola ${ }^{1}$, A. V. Lindfors ${ }^{1}$, T. Mielonen ${ }^{1}$, \\ T. Raatikainen ${ }^{5}$, S. Romakkaniemi ${ }^{1}$, S. N. Tripathi ${ }^{6,7}$, and H. Lihavainen $^{5}$ \\ ${ }^{1}$ Finnish Meteorological Institute, Kuopio, Finland \\ ${ }^{2}$ NASA Langley Research Center, Hampton, VA, USA \\ ${ }^{3}$ Department of Applied Physics, University of Eastern Finland, Kuopio, Finland \\ ${ }^{4}$ Laboratoire d'Optique Atmosphérique, Université de Lille1/CNRS, Villeneuve d'Ascq, France \\ ${ }^{5}$ Finnish Meteorological Institute, Helsinki, Finland \\ ${ }^{6}$ Department of Civil Engineering, Indian Institute of Technology, Kanpur, India \\ ${ }^{7}$ Centre for Environmental Science and Engineering, Indian Institute of Technology, Kanpur, India
}

Correspondence to: A. Arola (antti.arola@fmi.fi)

Received: 1 June 2015 - Published in Atmos. Chem. Phys. Discuss.: 10 August 2015

Revised: 22 October 2015 - Accepted: 26 October 2015 - Published: 17 November 2015

\begin{abstract}
The importance of light-absorbing organic aerosols, often called brown carbon $(\mathrm{BrC})$, has become evident in recent years. However, there have been relatively few measurement-based estimates for the direct radiative effect of BrC so far. In earlier studies, the AErosol RObotic NETwork (AERONET)-measured aerosol absorption optical depth (AAOD) and absorption Angstrom exponent (AAE) were exploited. However, these two pieces of information are clearly not sufficient to separate properly carbonaceous aerosols from dust, while imaginary indices of refraction would contain more and better justified information for this purpose. This is first time that the direct radiative effect (DRE) of $\mathrm{BrC}$ is estimated by exploiting the AERONETretrieved imaginary indices. We estimated it for four sites in the Indo-Gangetic Plain (IGP), Karachi, Lahore, Kanpur and Gandhi College. We found a distinct seasonality, which was generally similar among all the sites, but with slightly different strengths. The monthly warming effect up to $0.5 \mathrm{~W} \mathrm{~m}^{-2}$ takes place during the spring season. On the other hand, $\mathrm{BrC}$ results in an overall cooling effect in the winter season, which can reach levels close to $-1 \mathrm{~W} \mathrm{~m}^{-2}$. We then estimated similarly also the DRE of black carbon and total aerosol, in order to assess the relative significance of the $\mathrm{BrC}$ radiative effect in the radiative effects of other components. Even though $\mathrm{BrC}$ impact seems minor in this context, we demonstrated that it is not insignificant. Moreover, we demonstrated that
\end{abstract}

it is crucial to perform spectrally resolved radiative transfer calculations to obtain good estimates for the DRE of BrC.

\section{Introduction}

Aerosols affect the Earth's climate both directly (by scattering and absorbing radiation) and indirectly (by serving as nuclei for cloud droplets). Currently, aerosol forcing is the largest uncertainty in assessing the anthropogenic climate change (Myhre, 2013). Specifically, the role of carbonaceous aerosols is poorly understood. These particles can be divided into two categories: (1) black carbon (BC) is the main absorbing component present in atmospheric aerosols; and (2) organic carbon (OC) represents a significant and sometimes major (20-90\%) mass fraction of the sub-micron aerosol (Kanakidou et al., 2005; Zhang et al., 2007). Organic carbon has been most often assumed, in global models for instance, to be a non-absorbing or only slightly absorbing component. However, there is growing evidence that a substantial amount of organic aerosols absorb at UV and visible wavelengths, particularly strongly at shorter wavelengths (e.g., Kirchstetter et al., 2004; Martins et al., 2009). Nevertheless, so far there have been only relatively few measurementbased estimates for the direct radiative effect (DRE) of absorbing organic carbon, often called brown carbon, BrC. 
Both Chung et al. (2012) and Feng et al. (2013) exploited AErosol RObotic NETwork (AERONET) measurements to derive the radiative effect by $\mathrm{BrC}$; the former used an approach to separate dust and carbonaceous aerosols based on the AERONET-measured absorption Angstrom exponent (AAE), while the latter accounted for shortwave enhanced absorption by $\mathrm{BrC}$ in their global model and demonstrated an improved correspondence of modeled aerosol absorption optical depth (AAOD) and AERONET measurements, when BrC absorption was included in the model.

The approach of Chung et al. (2012) has evident difficulties in separating dust and carbonaceous aerosols by using an AAE, and arguably an approach using AERONET-retrieved imaginary indices of refraction would be more justified, as discussed also in Schuster et al. (2015a, b). We estimated the $\mathrm{BrC}$ fractions by using the method of Schuster et al. (2015a) for four AERONET sites in the Indo-Gangetic Plain (IGP), Karachi, Lahore, Kanpur and Gandhi College, and then calculated the corresponding radiative effect by $\mathrm{BrC}$. We moreover calculated similarly the DRE of BC and total aerosol, in order to assess the relative significance of the $\mathrm{BrC}$ radiative effect in carbonaceous or total aerosol radiative effects.

\section{Data and methods}

\subsection{AERONET data}

AERONET (AErosol RObotic NETwork) is a globally distributed network of automatic Sun and sky scanning radiometers that measure at several wavelengths, typically centered at $0.34,0.38,0.44,0.50,0.67,0.87,0.94$, and $1.02 \mu \mathrm{m}$. The AERONET UV filters ( 340 and $380 \mathrm{~nm}$ ) have a full width at half maximum (FWHM) of $2 \mathrm{~nm}$ as compared to $10 \mathrm{~nm}$ for all other channels. All of these spectral bands are utilized in the direct Sun measurements, while four of them are also used for the sky radiance measurements, 0.44 , $0.67,0.87$ and $1.02 \mu \mathrm{m}$. Spectral aerosol optical depth (AOD) is obtained from direct Sun measurements, and inversion products of other aerosol optical properties, such as single scattering albedo (SSA), refractive indices and the columnintegrated aerosol size distributions above the measurement site, are provided at the sky radiance wavelengths (Holben et al., 1998).

The estimated uncertainty in AOD (Level 2) is 0.01-0.02 and is primarily due to the calibration uncertainty (Eck et al., 1999). The uncertainty in the complex index of refraction depends on AOD; Dubovik et al. (2000) estimated errors on the order of $30-50 \%$ for the imaginary part and 0.04 for the real part of the refractive index for the cases of high aerosol loading (AOD at $440 \mathrm{~nm}$ larger than 0.5). Aerosol loading is very high in the IGP region; therefore, these uncertainty estimates are likely representative for our AERONET sites as well.
Since the shortest sky radiance wavelength is $440 \mathrm{~nm}$, AERONET wavelengths are not ideal for detecting $\mathrm{BrC}$ absorption, which is much stronger at shorter than at $440 \mathrm{~nm}$ wavelengths. However, it is also stressed that AOD is very high for all sites that were analyzed, allowing for sufficient robustness in the retrieved spectral signal in the imaginary refractive index.

In our study, we used Level 2 data of size distributions and refractive indices at four retrieval wavelengths $0.44,0.67$, 0.87 and 1.02. Moreover, we also included some Level 1.5 refractive indices, when $0.2<\operatorname{AOD}(440)<0.4$, but only when a quality-checked Level 2 size distribution exists. In other words, we applied otherwise the same rigorous quality control that is required for Level 2 data, but we only relaxed the AOD requirement at $440 \mathrm{~nm}$ from 0.4 to 0.2 . We selected on purpose also these cases of possibly somewhat lower AOD, in order to not bias our sample, and thus the estimate of the DRE, towards higher aerosol loading. However, the AOD at $440 \mathrm{~nm}$ is typically above 0.4 in the IGP region, so the set of almucantar refractive indices that we included turned out to be insignificantly different to that of the "full" Level 2 (not shown).

We included four AERONET sites for our data analysis, covering wide conditions in the Indo-Gangetic Plain (IGP): Karachi and Lahore in Pakistan, and Kanpur and Gandhi College in India. The measurements covered the following time periods: Gandhi College: 4/2006-3/2010; Kanpur: 1/20014/2012; Karachi: 9/2006-8/2011; Lahore: 4/2007-10/2011. Figure 1 shows the locations of these sites overlaid in the annual mean AOD map from MODIS Terra. In the IGP there are large local emissions of aerosols from various sources: heavy particulate pollution from industrial sources, strong vehicular emissions, use of fossil fuels, and widespread biomass and agricultural crop residue burning. In addition, the IGP is strongly affected by seasonal (pre-monsoon) mineral dust transported mainly from the Thar Desert (e.g., Jethva et al., 2005; Ram et al., 2010; Kedia et al., 2014). The seasonal monsoon rains are extremely vital for the IGP and strongly anchor one commonly used way to divide the year into four distinct seasons: winter (December-February), premonsoon (March-May), monsoon (June-August), and postmonsoon (September-November). The strong and seasonally varying aerosol sources in IGP result in a very distinct geographical pattern of elevated AOD, bounded in the north by the Himalayan foothills and to the south by lower-altitude mountains.

Figure 2 shows the monthly mean AOD and SSA at $440 \mathrm{~nm}$ for our study sites. It is noted that this data set includes all AOD values (from the inversion data set) without the AOD threshold of 0.2 that we applied for refractive indices and also for SSA shown in the lower plot. This figure then further illustrates that the AOD levels are typically high and why our selected set of refractive indices was not very different to the "full" Level 2. The relative fractions of Level 2 data out of our selected set from Level 1.5, for refractive in- 


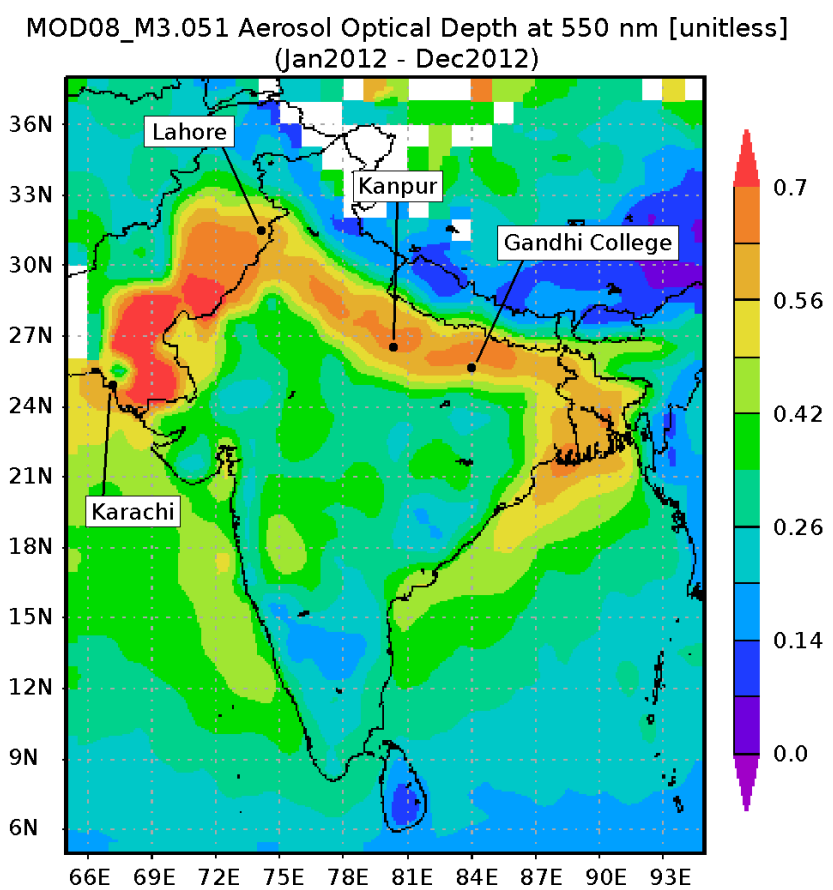

Figure 1. Annual mean AOD from MODIS Terra, with our AERONET study sites overlaid in the map. Source of MODIS data: http://disc.sci.gsfc.nasa.gov/giovanni.

dices, were about $60,97,85$, and $88 \%$ for Karachi, Lahore, Kanpur, and Gandhi College, respectively.

\subsection{Retrieval of $\mathrm{BrC}$ from AERONET measurements}

Schuster et al. (2005) developed an approach to retrieving black carbon concentration and specific absorption from AERONET retrievals of imaginary refractive indices, and it was further extended by Arola et al. (2011) to also include BrC. Recently, this method was further extended by Schuster et al. (2015a) to simultaneously include carbonaceous aerosols (both $\mathrm{BC}$ and $\mathrm{BrC}$ ) and also mineral dust in both fine and coarse modes separately.

Since the main details of the methodology are comprehensively described elsewhere, particularly in Schuster et al. (2015a), only the main points are summarized below. The approach is based on the best match between the modeled imaginary index and those retrieved by AERONET at four inversion wavelengths. For the modeled case, a scattering host is assumed to contain the following absorbing components: black carbon, brown carbon, hematite, and goethite. It is emphasized that this approach is able to detect only a subset of total organic carbon that is present, the part of absorbing organic carbon $(\mathrm{BrC})$. Therefore, the $\mathrm{BrC} / \mathrm{BC}$ ratios that we can infer from AERONET are not directly comparable with $\mathrm{OC} / \mathrm{BC}$ ratios available from in situ measurements. Table 1 provides the assumed refractive indices for each of these components. For the $\mathrm{BrC}$ refractive index, the values (a)

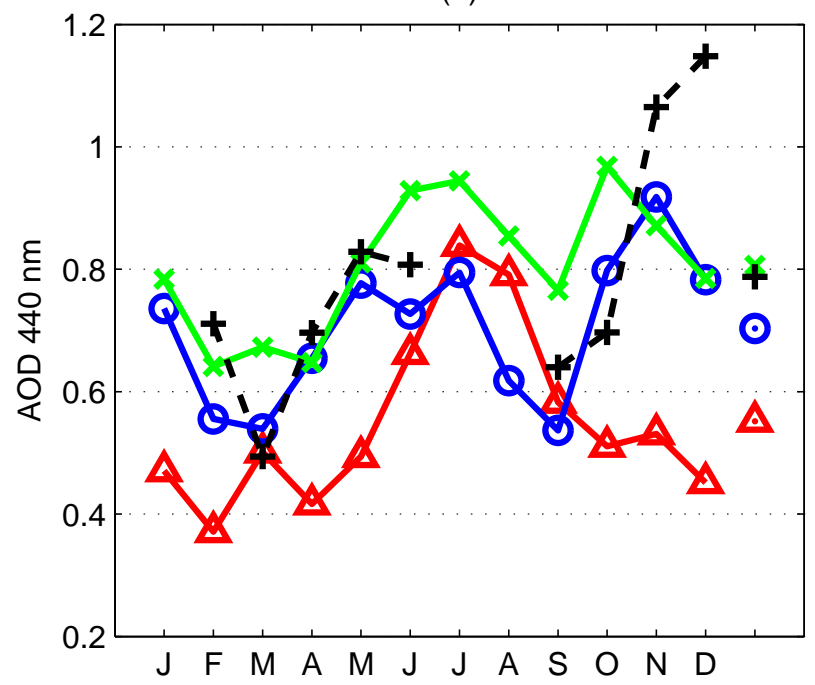

(b)

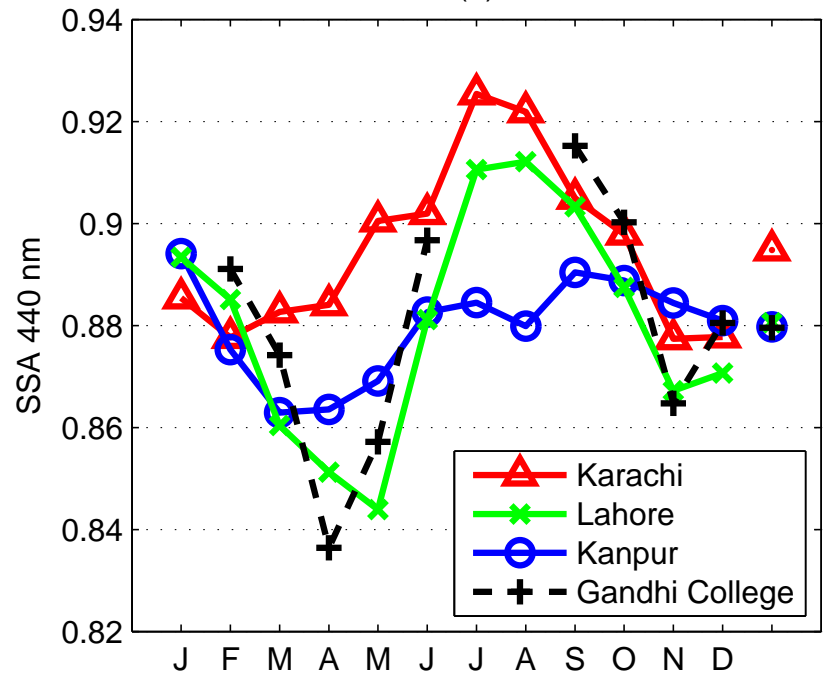

Figure 2. Monthly mean AOD and SSA at $440 \mathrm{~nm}$ for our selected AERONET sites. Annual means are indicated by a symbol after December.

given by Kirchstetter et al. (2004) were used, because globally they provide reasonable maximum and median fractions for $\mathrm{BrC}$ and also reasonable $\mathrm{BrC} / \mathrm{BC}$ ratios. It is noted that while the most recent version of Schuster et al. (2015a) uses Maxwell Garnett as the mixing rule for refractive indices, volume averaging was assumed in the data set used in our analysis. Arguably, given the scope of our study, the choice of the mixing rule is not essential, as long as it is applied consistently both in the AERONET retrieval and in our radiative transfer calculations. Moreover, it has been shown that the volume averaging results in very reasonable performance 
Table 1. Imaginary indices at $440 \mathrm{~nm}$ and RNIR (average of 670 , 870 , and $1020 \mathrm{~nm}$ ) assumed for each component in the retrieval of Schuster et al. (2015a).

\begin{tabular}{lrrrr}
\hline Wavelength & BrC & BC & Goethite & Hematite \\
\hline 440 & 0.063 & 0.79 & 0.068 & 1.23 \\
NIR & 0.003 & 0.79 & 0.1203 & 0.127 \\
\hline
\end{tabular}

in many cases, as demonstrated for instance in Lesins et al. (2002).

The AERONET-retrieved imaginary refractive indices at four wavelengths form the basis for retrieving the fractions of absorbing components, including $\mathrm{BrC}$.

The retrieval initially populates the fine mode with $\mathrm{BC}$ and $\mathrm{BrC}$ and the coarse mode with dust components (hematite and goethite). However, in some cases, in order to reach a realistic fit with the AERONET-retrieved imaginary indices, some of the fine mode has to additionally include iron oxides (hematite and goethite), and likewise some of the coarse mode can include carbonaceous aerosols. The average imaginary index of the three longest wavelengths (670, $870,1020 \mathrm{~nm}$ ), at red and near-infrared and hereinafter referred to by $k_{\mathrm{RNIR}}$, determines the black carbon fraction of the fine mode, for instance, while the difference between the imaginary index at $440 \mathrm{~nm}$ and $k_{\text {RNIR }}$ is due to the presence of BrC. Figure 3 shows the mean, median and variability (25 and $75 \%$ percentiles) of $k_{\text {RNIR }}$ and of the difference between $k_{440 \mathrm{~nm}}$ and $k_{\mathrm{RNIR}}$. Very strong seasonality is evident particularly in $k_{\mathrm{RNIR}}$, and thus in $\mathrm{BC}$. The variability is significant; nevertheless, the seasonality of $k_{\mathrm{RNIR}}$ is strong enough that there is no overlap between the months of highest and lowest values, between November-December and April-May, for instance. Figure 4 shows the monthly mean values of the imaginary index at $440 \mathrm{~nm}$ and the difference between $k_{440 \mathrm{~nm}}$ and $k_{\mathrm{RNIR}}$, in the (a) and (b) panels, respectively. Table 2 gives the number of imaginary indices that was included for each site to form the monthly means. Since we use the spectral imaginary index to derive $\mathrm{BC}$ and $\mathrm{BrC}$ volume fractions, there is understandably a visible similarity between $\mathrm{BC}$ fractions and $k_{\mathrm{RNIR}}$ (between panels a and c) and also $\mathrm{BrC}$ fractions and the difference between the imaginary index at $440 \mathrm{~nm}$ and RNIR (between panels $\mathrm{b}$ and d). The lowest panels, in turn, show the columnar concentrations of $\mathrm{BC}$ and $\mathrm{BrC}$. These were obtained by multiplying the $\mathrm{BC}$ and $\mathrm{BrC}$ volume fractions by AERONET-measured total volume (fine-mode + coarse-mode volume) and by the assumed densities. The densities of $1.8 \mathrm{~g} \mathrm{~cm}^{-3}$ and $1.2 \mathrm{~g} \mathrm{~cm}^{-3}$ were assumed for $\mathrm{BC}$ and $\mathrm{BrC}$, respectively.

There is a significant seasonality in both components of carbonaceous aerosols, particularly in $\mathrm{BC}$, the largest fractions occurring in the winter and late fall seasons. This BC seasonality agrees well with the seasonal pattern that has been obtained by the surface measurements in the IGP (Ram
Table 2. Number of AERONET observations for each month for the four sites. Data were collected for Karachi from September 2006 to August 2011, for Lahore from April 2007 to October 2011, for Kanpur from January 2001 to April 2012, and for Gandhi College from April 2006 to March 2010. Monthly data in parentheses were not included in the study due to the low number of observations.

\begin{tabular}{rrrrr}
\hline Month & Karachi & Lahore & Kanpur & Gandhi College \\
\hline 1 & 121 & 19 & 389 & $(7)$ \\
2 & 105 & 13 & 543 & 23 \\
3 & 176 & 107 & 746 & 149 \\
4 & 165 & 186 & 535 & 211 \\
5 & 136 & 172 & 626 & 307 \\
6 & 90 & 139 & 365 & 109 \\
7 & 46 & 83 & 49 & $(8)$ \\
8 & 14 & 45 & 62 & $(5)$ \\
9 & 129 & 96 & 253 & 42 \\
10 & 239 & 116 & 508 & 72 \\
11 & 173 & 114 & 433 & 54 \\
12 & 118 & 10 & 466 & 68 \\
\hline
\end{tabular}

et al., 2010), who observed a very distinct BC seasonality. Moreover, they observed similar seasonal patterns for both $\mathrm{BC}$ and $\mathrm{OC}$, highest concentrations in late fall/winter due to various sources of carbonaceous aerosols, and biomass burning and wood fuel burning for domestic use, for instance. As noted before, we can only detect absorbing OC via AERONET, so our BrC pattern cannot be, therefore, directly compared with these available OC measurements. However, generally our $\mathrm{BrC}$ seasonality agrees also rather well with the seasonality of OC in the IGP observed by Ram et al. (2010), while the clearest difference seems to be in spring, when AERONET-based BrC levels are enhanced. As shown by Vadrevu and Lasko (2015), for instance, in the IGP there is a bi-modal burning season, peaking in the spring and late fall/winter; this is captured by our $\mathrm{BrC}$ retrievals, suggesting that a large fraction of $\mathrm{OC}$ emissions in spring and late fall includes brown carbon.

\subsection{Calculation of the radiative effect}

The radiative transfer calculations were performed by using the libRadtran package (Mayer and Kylling, 2005). We used a two-stream solver and correlated-k approximation of Kato et al. (1999) with bands from 1 to 31 (from 240.1 to $3991 \mathrm{~nm}$ ) to cover the entire shortwave (SW) range. The direct radiative effect of $\mathrm{BrC}$, the $\mathrm{DRE}$ of $\mathrm{BrC}$, at the top of the atmosphere (TOA) was calculated on a monthly basis, as the difference between two cases: including all aerosols and excluding $\mathrm{BrC}$. The former was based on monthly mean size distribution and refractive index, while the latter set was formed by excluding the volume fraction of $\mathrm{BrC}$. By excluding the $\mathrm{BrC}$ fraction, both refractive index and size distribution were then modified. The refractive index for the "non-BrC" case was created by the volume averaging mixing rule and including all the 

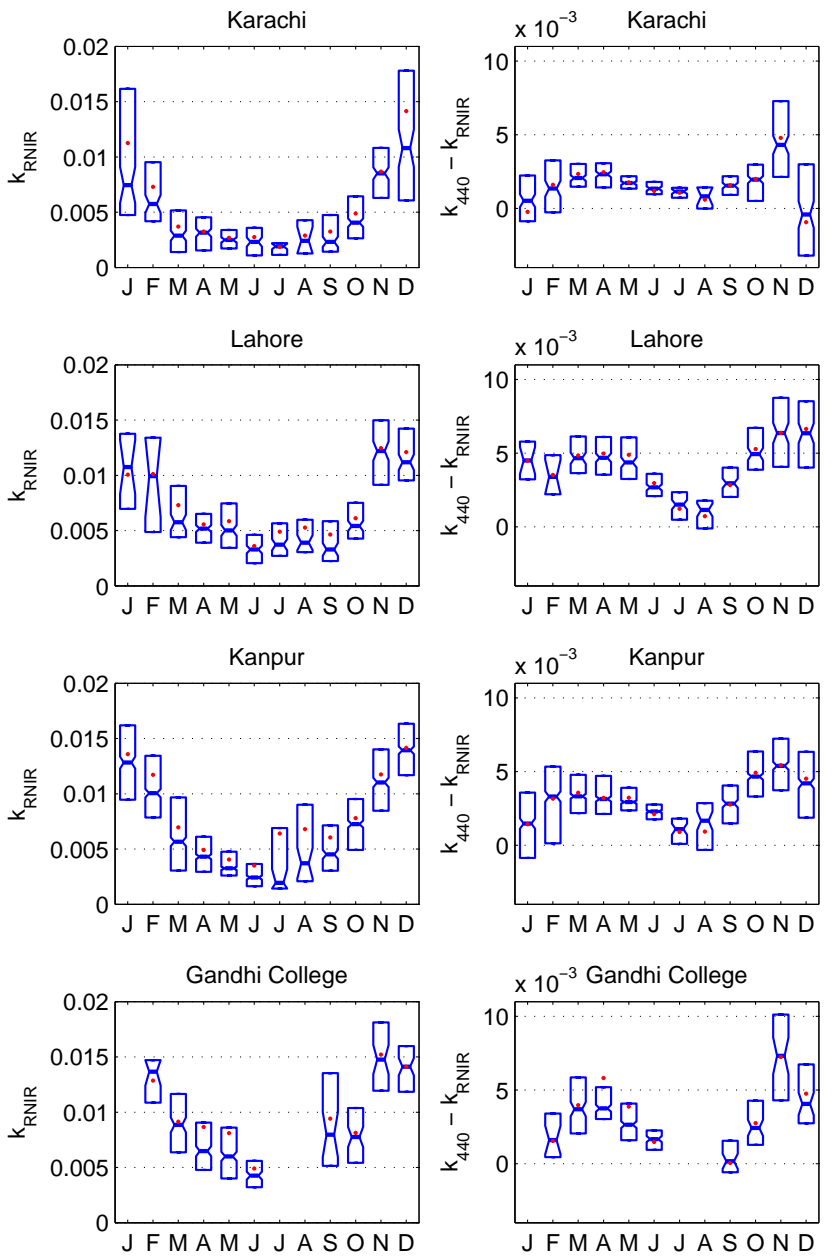

Figure 3. Boxplot of monthly imaginary indices: average of the imaginary index at 670,870 , and $1020 \mathrm{~nm}\left(k_{\mathrm{RNIR}}\right)$ in the left panel; difference between the imaginary index at $440 \mathrm{~nm}$ and $k_{\mathrm{RNIR}}$ in the right panel, showing the 25 and $75 \%$ percentiles. The boxplot indicating the median and mean is additionally shown by red dots.

other components except for $\mathrm{BrC}$ (the scattering host, black carbon, goethite and hematite). The volume size distribution of the "non-BrC" case was formed by reducing the volume in all size ranges by the volume fraction of $\mathrm{BrC}$ separately in the fine and coarse modes. By defining the DRE of $\mathrm{BrC}$ in this fashion, aerosols are considered internally mixed, which is also the case in AERONET inversion methods. We adopted a similar approach to calculate additionally the DRE of BC and total aerosol.

Size distributions and refractive indices were then used for calculating the aerosol optical properties for the non-BrC mixture, which was done by utilizing the spheroid aerosol model by Dubovik et al. (2002). The model is consistent with the one used for the retrieval of AERONET products, assuming a portion of the aerosols to be spheroids, as described by Dubovik et al. (2006). This way both the "all aerosols" mixture and the "non-BrC" mixture were described (a)
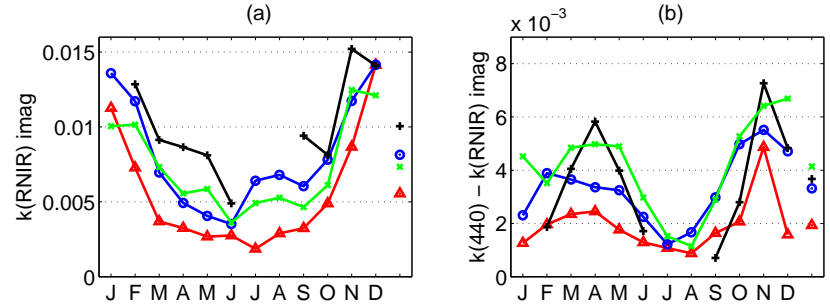

(c)

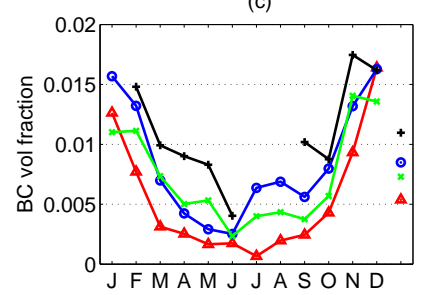

(e)

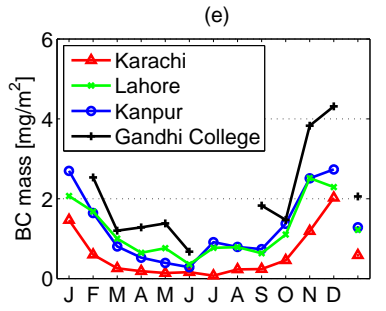

(d)

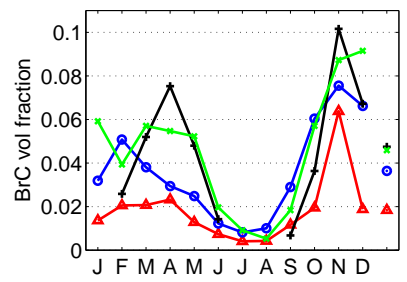

(f)

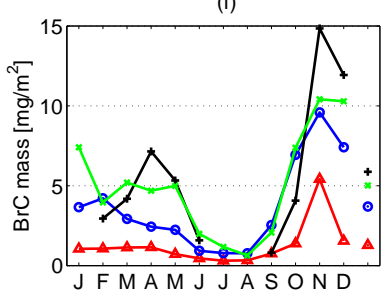

Figure 4. Monthly averages of imaginary indices and the retrieved fraction of carbonaceous aerosols: (a) average of the imaginary index at 670, 870, and $1020 \mathrm{~nm}\left(k_{\mathrm{RNIR}}\right)$; (b) difference between the imaginary index at $440 \mathrm{~nm}$ and $k_{\mathrm{RNIR}}$; retrieved volume fractions of (c) $\mathrm{BC}$ and (d) $\mathrm{BrC}$; retrieved columnar concentrations in $\mathrm{mg} \mathrm{m}^{-2}$ of (e) $\mathrm{BC}$ and (f) $\mathrm{BrC}$. Corresponding annual averages are given after December.

by their respective spectral AOD, SSA and asymmetry parameters, which were finally used estimating the DRE of $\mathrm{BrC}$. For the calculations of aerosol direct radiative effect, surface albedo is also a very crucial input. In our simulations we used monthly spectral solar zenith angle dependent albedo from the AERONET inversion product (i.e., MODISbased albedo). The surface albedo was linearly interpolated between the inversion data wavelengths. The surface albedo value at $440 \mathrm{~nm}$ was extrapolated to the shorter wavelengths as well, while the wavelengths larger than $1020 \mathrm{~nm}$ were linearly extrapolated so that the surface albedo at $5 \mu \mathrm{m}$ is decreased to 0.01. The DRE of $\mathrm{BrC}$ (and $\mathrm{BC}$ and total aerosol) at TOA was simulated with a $1 \mathrm{~h}$ time step over a $24 \mathrm{~h}$ diurnal cycle with solar insolation of the 15th day of each month.

\section{Results}

Figure 5 shows our simulated radiative effects by $\mathrm{BrC}$ in the lowest panel, while the upper and middle panels include relevant parameters to interpret these results. The difference in AOD at $440 \mathrm{~nm}$ (in blue) and at RNIR (average of 670 
1020 , in red) between the simulations with and without $\mathrm{BrC}$ is shown in the upper panel. The middle panel shows similar results for SSA, which are particularly relevant quantities now to understand whether the overall effect is warming or cooling when $\mathrm{BrC}$ is added in. It is emphasized that while brown carbon is absorbing at the shortest wavelengths, determined by the measurement at $440 \mathrm{~nm}$ in our case, it is almost purely scattering at RNIR wavelengths. Therefore, when $\mathrm{BrC}$ is included, there are typically two spectrally competing effects taking place, warming at the shortest and cooling at the longer wavelengths. And we can detect these effects also in the middle panel of Fig. 5. In principle, the scattering coefficient at RNIR increases when $\mathrm{BrC}$ is added, while the absorption coefficient remains close to a constant. Therefore, SSA (= scattering/[scattering + absorption]) also increases, and the SSA difference at RNIR, shown by the dashed red lines, is therefore essentially always positive. On the other hand, both scattering and absorption coefficients increase upon addition of $\mathrm{BrC}$ at the 440 wavelength. Hence, SSA decreases with addition of $\mathrm{BrC}$ at that wavelength, since scattering and absorption combined increase more than scattering alone. Thus, the blue lines are always negative.

The relative strength of these spectrally separated cooling and warming effects will eventually determine whether the overall spectrally integrated shortwave direct effect is cooling or warming. And the strength of both these effects, in turn, depends on the relative fractions of the other components present. In our version of absorbing components by Schuster et al. (2015a), volume averaging has been applied, consistently both in the retrieval and when we have formed new refractive indices for the "non-BrC" case in our simulations. Therefore, it is also now rather straightforward to give a quantitative estimate of the changes in the imaginary index with and without $\mathrm{BrC}$ at $440 \mathrm{~nm}$ and a RNIR range for any given fractions of these components. It is now possible to separate $\mathrm{BrC}$ influence this way, since we have assumed that $\mathrm{BC}$ has a constant refractive index at all wavelengths, where $\mathrm{BrC}$ is essentially non-absorbing but absorbs at $440 \mathrm{~nm}$.

As can be seen from Table 1, BC has the largest imaginary index at RNIR wavelengths, and therefore the most sensitive change towards cooling at RNIR takes place when $\mathrm{BrC}$ is added to the mixture of relatively large amounts of black carbon. These changes in the imaginary index, with and without $\mathrm{BrC}$, essentially determine the SSA patterns we see in the middle panel of Fig. 5. Therefore, it is useful and clarifying to further interpret our BrC DRE results by focusing next on these changes. Figure 6 shows the change in imaginary index (based on volume averaging), both at $440 \mathrm{~nm}$ and RNIR range, if $\mathrm{BrC}$ is added in. The scale of both the $\mathrm{BC}$ and $\mathrm{BrC}$ volume fractions in this figure was determined by the range retrieved for our IGP sites (in the middle panel of Fig. 4). It is evident that including $\mathrm{BrC}$ results in an increase of the imaginary index difference at $440 \mathrm{~nm}$, which is a strong function of the $\mathrm{BrC}$ volume fraction but depends only slightly on the $\mathrm{BC}$ fraction (shown by the solid isolines of the figure). At RNIR range the behavior is quite different: at low enough $\mathrm{BC}$ fractions, $\mathrm{BrC}$ can result in an increase in the imaginary index; however, most often the opposite is true (shown by the color bar and dotted isolines of the figure). Moreover, this decrease in the imaginary index with increasing $\mathrm{BrC}$ volume fraction depends also relatively strongly on the $\mathrm{BC}$ volume fraction. This means that for a given $\mathrm{BrC}$ fraction, the larger the volume fraction of $\mathrm{BC}$, the stronger the cooling effect at RNIR wavelengths.

Our estimated values for the DRE of BrC shown in Fig. 5, and the corresponding changes in SSA (in the middle panels), are best understood with the help of Fig. 6 and there by the behavior at RNIR in particular. Therefore, this figure includes additionally the retrieved monthly averaged volume fractions of $\mathrm{BC}$ and $\mathrm{BrC}$ for 2 months, April and November, selected here to roughly represent the periods of the strongest warming and cooling. The name of the site is indicated next to the month of April; thus, the other end of the line corresponds to November. As can be seen from the middle panel of Fig. 5, the largest positive SSA difference at RNIR, when $\mathrm{BrC}$ is included, is in Gandhi College in November, which consistently corresponds to the case of the most negative change of the RNIR imaginary index in Fig. 6. This is then also the case of the strongest overall cooling by $\mathrm{BrC}$. The spectral SSA changes due to the $\mathrm{BrC}$, which are illustrated in the middle panel of Fig. 5, mainly determine whether overall cooling or warming takes place. However, the actual magnitude of these spectral cooling and warming contributions, in turn, are also substantially influenced by the absolute $\mathrm{BrC}$ fractions in AOD, which are shown in the upper panel of Fig. 5. It is evident that the large values of $\mathrm{BrC}$ optical depths at the end of the year in Gandhi College, in addition to the large increase of SSA at RNIR wavelengths, also strongly contribute to the considerable DRE of BrC. Brown carbon causes cooling in the other sites as well during this time of the year, when BC fractions are at their highest. On the other hand, the warming takes place typically in the spring season in all the sites, when $\mathrm{BC}$ fractions are lower but $\mathrm{BrC}$ fractions are at relatively high levels (shown in Figs. 4 and 6). To summarize, the common pattern is the warming by $\mathrm{BrC}$ in the spring season and cooling in the late fall and winter (except for Karachi where cooling takes place only in NovemberDecember), and this change of sign in the radiative effect by $\mathrm{BrC}$ is due to the different relative fractions of $\mathrm{BC}$ during the spring and late fall seasons.

The annually averaged DRE of $\mathrm{BrC}$ is slightly positive for Karachi, while Lahore and Kanpur have slight cooling by $\mathrm{BrC}$. The annually averaged negative forcing in Gandhi College is somewhat more profound due to the strongest cooling in the November-December period. The strongest cooling is due to the highest total $\mathrm{BrC}$ concentrations and thus AOD corresponding to the $\mathrm{BrC}$ during this period, as can be seen from the upper panel of Fig. 5.

Finally, Table 3 gives monthly DRE values for the following cases of included aerosol types: total aerosols, $\mathrm{BrC}$, 
Table 3. Monthly DRE $\left(\mathrm{W} \mathrm{m}^{-2}\right)$ of different aerosol types, "non-BrC" referring to the case with all aerosols other than BrC. The annual mean is shown after December. The three missing months of Gandhi College had fewer than 10 observations.

\begin{tabular}{|c|c|c|c|c|c|c|c|c|c|c|c|c|c|}
\hline & Jan & Feb & Mar & Apr & May & Jun & Jul & Aug & Sep & Oct & Nov & Dec & Annual \\
\hline \multicolumn{14}{|l|}{ Karachi } \\
\hline Total & -6.06 & -4.72 & -6.30 & -4.72 & -5.67 & -6.18 & -11.28 & -7.55 & -5.91 & -7.08 & -6.81 & -5.62 & -6.49 \\
\hline $\mathrm{BrC}$ & -0.04 & 0.02 & 0.22 & 0.22 & 0.09 & 0.10 & 0.06 & 0.13 & 0.18 & 0.10 & -0.15 & -0.07 & 0.07 \\
\hline $\mathrm{BC}$ & 5.91 & 4.66 & 3.54 & 2.25 & 1.42 & 2.73 & 0.93 & 3.92 & 3.22 & 3.57 & 4.99 & 6.06 & 3.60 \\
\hline Non-BrC & -6.02 & -4.75 & -6.52 & -4.94 & -5.76 & -6.28 & -11.34 & -7.69 & -6.09 & -7.18 & -6.66 & -5.55 & -6.56 \\
\hline \multicolumn{14}{|l|}{ Lahore } \\
\hline Total & -12.82 & -10.27 & -7.98 & -7.18 & -6.62 & -9.42 & -10.29 & -8.95 & -10.23 & -13.72 & -11.48 & -10.92 & -9.99 \\
\hline $\mathrm{BrC}$ & -0.45 & -0.24 & 0.02 & 0.28 & 0.50 & 0.44 & 0.13 & 0.04 & -0.02 & -0.05 & -0.46 & -0.57 & -0.03 \\
\hline $\mathrm{BC}$ & 5.00 & 5.75 & 6.61 & 5.92 & 8.35 & 4.83 & 6.96 & 6.29 & 4.30 & 5.90 & 7.51 & 5.70 & 6.09 \\
\hline Non-BrC & -12.37 & -10.03 & -8.01 & -7.46 & -7.12 & -9.86 & -10.42 & -8.99 & -10.22 & -13.67 & -11.01 & -10.34 & -9.96 \\
\hline \multicolumn{14}{|l|}{ Kanpur } \\
\hline Total & -10.05 & -6.06 & -4.83 & -5.32 & -5.72 & -6.57 & -3.36 & -2.79 & -5.80 & -9.84 & -11.08 & -10.16 & -6.80 \\
\hline $\mathrm{BrC}$ & -0.21 & -0.18 & 0.05 & 0.23 & 0.33 & 0.11 & 0.12 & 0.05 & -0.01 & -0.10 & -0.36 & -0.31 & -0.02 \\
\hline $\mathrm{BC}$ & 6.88 & 6.71 & 6.13 & 5.91 & 4.98 & 4.30 & 10.74 & 7.63 & 4.24 & 6.35 & 7.84 & 6.93 & 6.55 \\
\hline Non-BrC & -9.84 & -5.88 & -4.88 & -5.55 & -6.06 & -6.67 & -3.48 & -2.84 & -5.79 & -9.74 & -10.72 & -9.85 & -6.78 \\
\hline \multicolumn{14}{|c|}{ Gandhi Coll } \\
\hline Total & - & -9.18 & -6.51 & -2.08 & -3.88 & -9.06 & - & - & -7.31 & -10.14 & -10.42 & -13.00 & -7.95 \\
\hline $\mathrm{BrC}$ & - & -0.19 & -0.15 & 0.42 & 0.30 & 0.14 & - & - & -0.05 & -0.23 & -0.83 & -0.68 & -0.14 \\
\hline $\mathrm{BC}$ & - & 7.56 & 5.36 & 9.92 & 10.83 & 6.44 & - & - & 5.42 & 5.51 & 9.53 & 8.73 & 7.70 \\
\hline Non-BrC & - & -8.98 & -6.36 & -2.50 & -4.18 & -9.20 & - & - & -7.26 & -9.92 & -9.59 & -12.32 & -7.81 \\
\hline
\end{tabular}
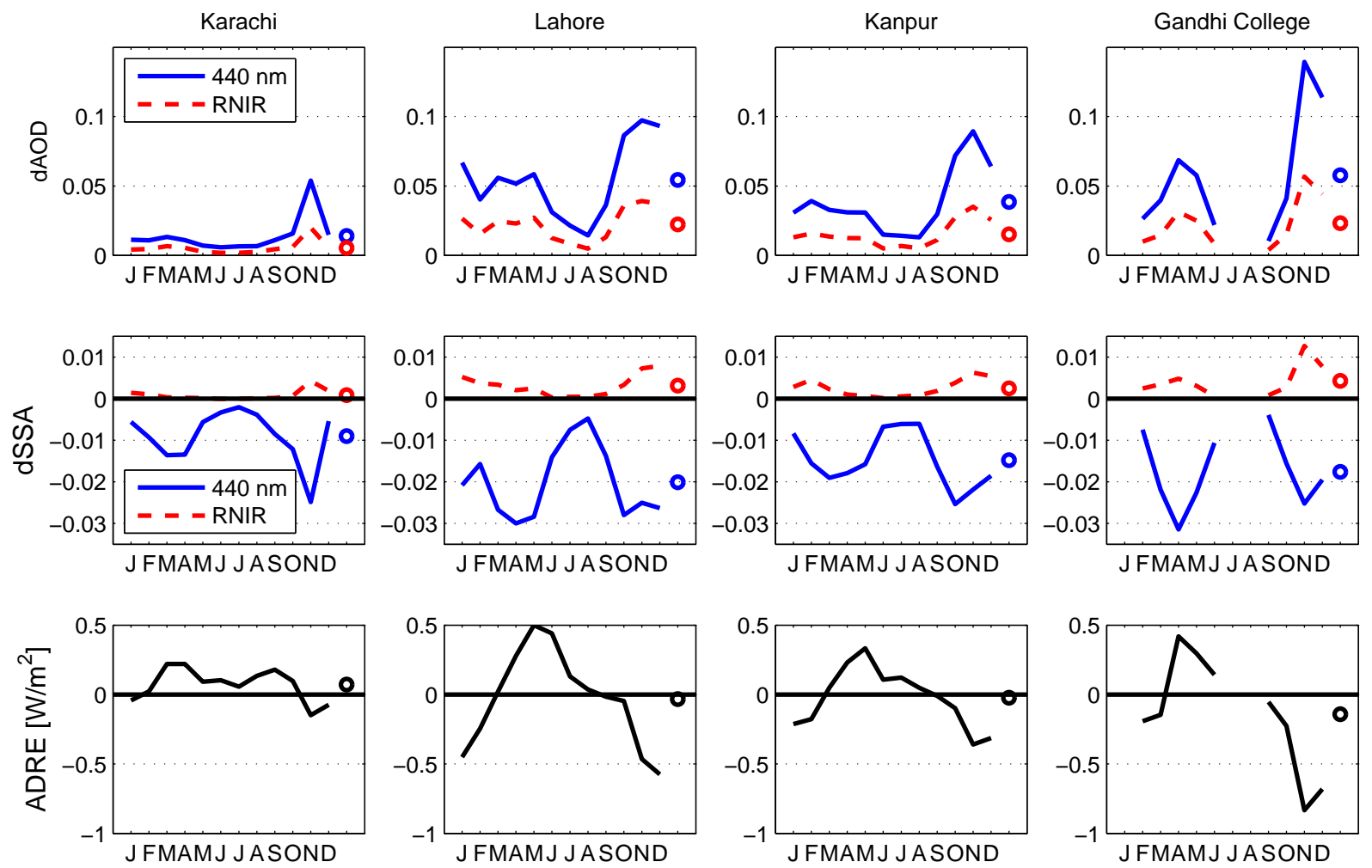

Figure 5. Upper panel: monthly averages of the difference in AOD at $440 \mathrm{~nm}$ (blue) and at RNIR (red) between simulations with and without $\mathrm{BrC}$. Middle panel: corresponding cases for SSA. Lower panel: monthly average DRE of BrC. Corresponding annual averages are given by the symbol after December. 


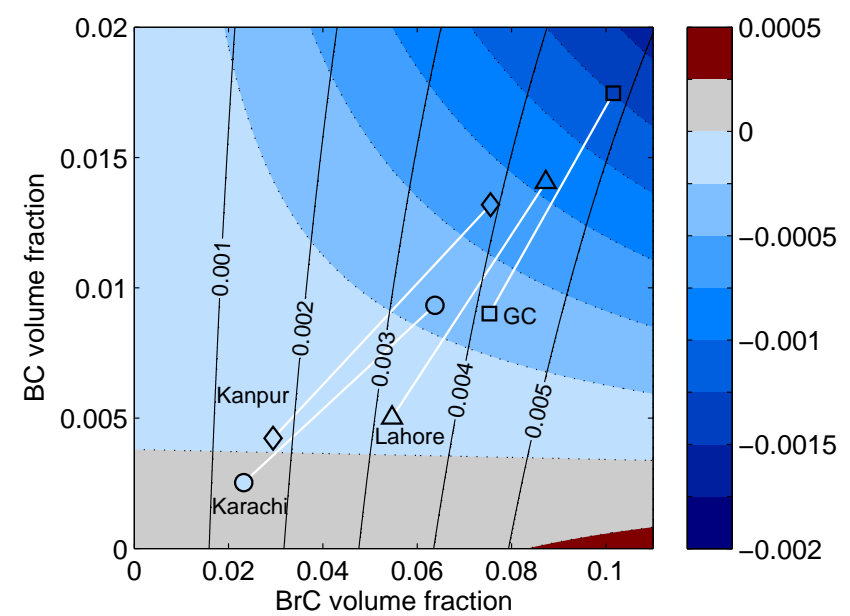

Figure 6. Difference between the imaginary index with and without $\mathrm{BrC}$ included at $440 \mathrm{~nm}$ (solid isolines) and at RNIR wavelengths (by color bar and dotted isolines) as a function of $\mathrm{BC}$ and $\mathrm{BrC}$ volume fractions. Monthly mean values of $\mathrm{BC}$ and $\mathrm{BrC}$ volume fractions are shown for each site by symbols and lines for 2 months: April with the name of the site next to it and November at the other end of the line.

$\mathrm{BC}$ and additionally the case with all aerosols except for $\mathrm{BrC}$ ("non-BrC"). One can conclude, for example, that during April-May the relative magnitude of warming by $\mathrm{BrC}$ is about $5-7 \%$ of total aerosol cooling, except for Gandhi College, where it is as high as $20 \%$ in April due to the strong BC absorption and thus small overall cooling. On the other hand, the importance of accounting properly for the spectral $\mathrm{BrC}$ effect in the DRE of carbonaceous aerosols $(\mathrm{BrC}+\mathrm{BC})$ can be emphasized by comparing it to $\mathrm{BC}$ (thus the second and third rows of Table 3). This comparison illustrates that $\mathrm{BrC}$ absorption can reach about $10 \%$ of carbonaceous aerosol absorption.

As discussed above, whether the spectrally integrated SW direct radiative effect by $\mathrm{BrC}$ results in cooling or warming is determined by the relative strength of two opposing effects, warming at shorter wavelengths and cooling at the RNIR range. Thus it is crucial to properly take both of these spectral effects into account, which is often true for total aerosol DRE calculations as well. However, it has also been common to estimate the optical properties at mid-visible only and then apply some simple approximations and assumptions to account for spectral dependence in direct radiative effect calculations (e.g., Chylek and Wong, 1995; Haywood and Shine , 1995). Therefore, we wanted to also assess how well DRE based on the mid-visible range only could represent the entire SW range. We repeated our calculations for the DRE of $\mathrm{BrC}$, but using Kato band no. 10 only, since it has the central wavelength at $544.8 \mathrm{~nm}$ (range from 540 to $549.5 \mathrm{~nm}$ ). We estimated additionally the direct radiative effect of $\mathrm{BC}$ and total aerosol, using an identical approach that we described above for BrC. Thus the DRE of BC, for instance, was based (a)

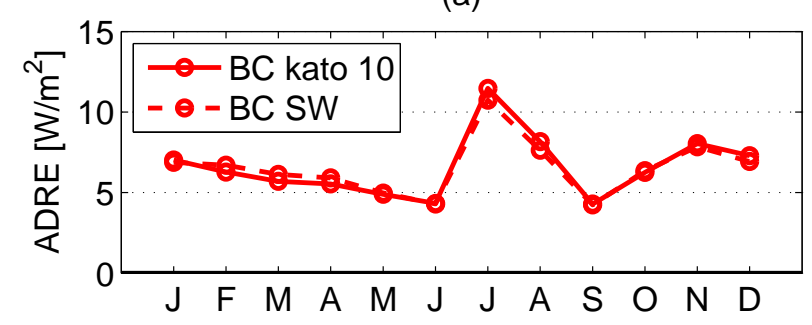

(b)

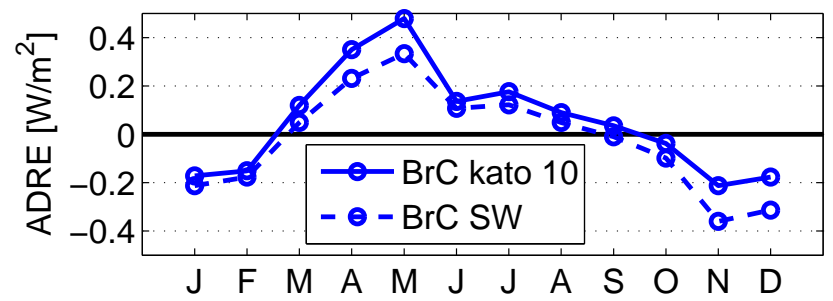

(c)

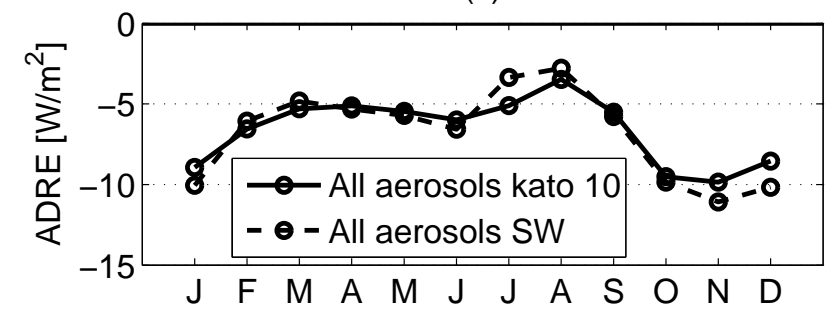

Figure 7. Direct radiative effect in Kanpur based on two spectral ranges of Kato bands: (1) all Kato bands and (2) Kato band no. 10 (center wavelength at $544.8 \mathrm{~nm}$ ), but scaled to account for the full $\mathrm{SW}$ range. Upper panel: for $\mathrm{BC}$; middle panel: for $\mathrm{BrC}$; lower panel: for total aerosol.

on two radiative transfer runs: the case of all aerosols, and without BC. We then calculated the mean ratio of the DRE from the following two runs (separately for the $\mathrm{BrC}, \mathrm{BC}$ and total aerosol cases): (1) actual spectrally resolved radiative transfer calculation including all the Kato bands, i.e., by the same approach we have applied in our results shown earlier, and (2) the radiative effect from the single Kato band no. 10 only. This mean ratio was then used as a conversion factor to get a full SW DRE from a single-band DRE radiative transfer run, and to make these two approaches comparable. Figure 7 shows the DRE in Kanpur from these two cases: (1) actual spectrally resolved radiative transfer calculation including all the Kato bands, and (2) the radiative effect from the single Kato band no. 10 only, but scaled to represent the full SW.

It is evident that a single wavelength approach can produce a rather stable estimate for the $\mathrm{BC}$ radiative effect; the relative error is within $\pm 10 \%$, which is understandable given the spectrally invariant imaginary index of BC. On the other hand, both the $\mathrm{BrC}$ and total aerosol cases can reach significantly higher relative differences. SW radiative effects of $\mathrm{BrC}$ and total aerosol include typically wavelength ranges of both cooling and warming effects that a single wavelength 
approach cannot therefore properly capture. Spectral dependence of the DRE of $\mathrm{BrC}$ was illuminated above, while the spectral dependence of the total aerosol DRE is typically different; for instance, in Kanpur, SSA is low enough and surface albedo high enough at RNIR range during the summer months to produce warming at these longer wavelengths (not shown), although the overall spectrally integrated total aerosol direct radiative effect is always negative, as shown in the lower panel of Fig. 7.

\section{Conclusions}

The importance of light-absorbing organic aerosols has become evident in recent years. It is important to understand and take into account the effects of $\mathrm{BrC}$ not only for the aerosol radiative forcing, but also for surface UV radiation levels and remote sensing from satellite in the UV wavelengths. However, there are relatively few measurementbased estimates for the direct radiative effect of $\mathrm{BrC}$ so far. In those earlier studies, the AERONET-measured AAOD and AAE have been exploited, while this is the first time that the DRE of $\mathrm{BrC}$ is estimated by exploiting the AERONETretrieved imaginary indices. With AAOD and AAE information only, there is little information about the aerosol size, and thus the separation of dust and $\mathrm{BrC}$ absorption becomes unclear, while arguably with the use of imaginary indices (Schuster et al., 2015b), they can be better distinguished. We estimated the radiative effect of $\mathrm{BrC}$ for four AERONET sites in the Indo-Gangetic Plain (IGP): Karachi, Lahore, Kanpur and Gandhi College. We found a distinct seasonality, which was generally similar among all the sites, but with slightly different strengths. The warming by $\mathrm{BrC}$ takes place during the spring season, due to the relatively low $\mathrm{BC}$ fractions, so that the scattering effect by $\mathrm{BrC}$ at RNIR does not become significant enough and the absorption at the shortest wavelengths dominates in the spectrally integrated radiative effect. The opposite is true in late fall and in the winter period, when the $\mathrm{BC}$ fractions are more substantial, and therefore the cooling effect at RNIR wavelengths becomes more significant in the overall shortwave radiative effect by $\mathrm{BrC}$.

We estimated the DRE of $\mathrm{BrC}$ as a difference of two radiative transfer runs: the case for all aerosols and without $\mathrm{BrC}$. We estimated the DRE of BC and total aerosol similarly and, in that context, it became evident that the role of $\mathrm{BrC}$ is not insignificant and, moreover, it is crucial to properly account for its spectral radiative effect. The DRE of $\mathrm{BrC}$ can reach magnitudes of $10 \%$ relative to $\mathrm{BC}$, so it is not negligible in the DRE of absorbing carbonaceous $(\mathrm{BC}+\mathrm{BrC})$ aerosols. Moreover, the DRE of $\mathrm{BrC}$ exhibited a distinct seasonality in the four sites we included in our analysis. Therefore, this study stresses the need to account for absorbing OC, not to assume it is purely scattering. And it is then particularly crucial to properly account for both warming effect at the lowest and cooling effect at the longer wavelengths, when forming the overall SW direct radiative effect of BrC.

Acknowledgements. This study was supported by the Academy of Finland (project number 264242).

Edited by: E. Gerasopoulos

\section{References}

Arola, A., Schuster, G., Myhre, G., Kazadzis, S., Dey, S., and Tripathi, S. N.: Inferring absorbing organic carbon content from AERONET data, Atmos. Chem. Phys., 11, 215-225, doi:10.5194/acp-11-215-2011, 2011.

Chung, C., Ramanathan, V., and Decremer, D.: Observationally constrained estimates of carbonaceous aerosol radiative forcing, P. Natl. Acad. Sci., 109, 11624-11629, 2012.

Chylek, P. and Wong, J.: Effect of absorbing aerosols on global radiation budget, Geophys. Res. Lett., 22, 929-931, 1995.

Dubovik, O., Smirnov, A., Holben, B. N., King, M. D., Kaufman, Y. J., Eck, T. F., and Slutsker, I.: Accuracy assessment of aerosol optical properties retrieval from AERONET sun and sky radiance measurements, J. Geophys. Res., 105, 9791-9806, 2000.

Dubovik, O., Holben, B. N., Lapyonok, T., Sinyuk, A., Mishchenko, M. I., Yang, P., and Slutsker, I.: Non-spherical aerosol retrieval method employing light scattering by spheroids, Geophys. Res. Lett., 29, 54-1-54-4, doi:10.1029/2001GL014506, 2002.

Dubovik, O., Sinyuk, A., Lapyonok, T., Holben, B. N., Mishchenko, M., Yang, P., Eck, T. F., Volten, H., Muñoz, O., Veihelmann, B., van der Zande, W. J., Leon, J.-F., Sorokin, M., and Slutsker, I.: Application of spheroid models to account for aerosol particle nonsphericity in remote sensing of desert dust, J. Geophys. Res.Atmos., 111, D11208, doi:10.1029/2005JD006619, 2006.

Eck, T., Holben, B., Reid, J. S., Dubovik, O., Smirnov, A., O'Neill, N. T., Slutsker, I., and Kinne, S., Wavelength dependence of the optical depth of biomass burning urban and desert dust aerosols, J. Geophys. Res., 104, 31333-31349, doi:10.1029/1999JD900923, 1999.

Feng, Y., Ramanathan, V., and Kotamarthi, V. R.: Brown carbon: a significant atmospheric absorber of solar radiation?, Atmos. Chem. Phys., 13, 8607-8621, doi:10.5194/acp-13-8607-2013, 2013.

Haywood, J. M. and Shine, K. P.: The effect of anthropogenic sulfate and soot aerosol on the clear sky planetary radiation budget, Geophys. Res. Lett., 22, 602-606, 1995.

Holben, B. N., Eck, T. F., Slutsker, I., Tanre, D., Buis, J. P., Setzer, A., Vermote, E., Reagan, J. A., Kaufman, Y., Nakajima, T., Lavenu, F., Jankowiak, I., and Smirnov, A.: AERONET - A federated instrument network and data archive for aerosol characterization, Rem. Sens. Environ., 66, 1-16, 1998.

Jethva, H., Satheesh, S. K., and Srinivasan, J.: Seasonal variability of aerosols over the Indo-Gangetic basin, J. Geophys. Res., 110, D21204, doi:10.1029/2005JD005938, 2005.

Kanakidou, M., Seinfeld, J. H., Pandis, S. N., Barnes, I., Dentener, F. J., Facchini, M. C., Van Dingenen, R., Ervens, B., Nenes, A., Nielsen, C. J., Swietlicki, E., Putaud, J. P., Balkanski, Y., Fuzzi, S., Horth, J., Moortgat, G. K., Winterhalter, R., Myhre, C. E. 
L., Tsigaridis, K., Vignati, E., Stephanou, E. G., and Wilson, J.: Organic aerosol and global climate modelling: a review, Atmos. Chem. Phys., 5, 1053-1123, doi:10.5194/acp-5-1053-2005, 2005.

Kato, S., Ackerman, T., Mather, J., and Clothiaux, E.: The kdistribution method and correlated-k approximation for shortwave radiative transfer model, J. Quant. Spectrosc. Ra., 62, 109121, 1999.

Kedia, S., Ramachandran, S., Holben, B. N., and Tripathi, S. N.: Quantification of aerosol type, and sources of aerosols over the Indo-Gangetic Plain, Atmos. Environ., 98, 607-619, doi:10.1016/j.atmosenv.2014.09.022, 2014.

Kirchstetter, T. W., Novakov, T., and Hobbs, P. V.: Evidence that the spectral dependence of light absorption by aerosols is affected by organic carbon, J. Geophys. Res., 109, D21208, doi:10.1029/2004JD004999, 2004.

Lesins, G., Chylek, P., and Lohmann, U.: A study of internal and external mixing scenarios and its effect on aerosol optical properties and direct radiative forcing, J. Geophys. Res., 107, doi:10.1029/2001JD000973, 2002.

Martins, J. V., Artaxo, P., Kaufman, Y. J., Castanho, A. D., and Remer, L. A.: Spectral absorption properties of aerosol particles from 350-2500nm, Geophys. Res. Lett., 36, L13810, doi:10.1029/2009GL037435, 2009.

Mayer, B. and Kylling, A.: Technical note: The libRadtran software package for radiative transfer calculations - description and examples of use, Atmos. Chem. Phys., 5, 1855-1877, doi:10.5194/acp-5-1855-2005, 2005.

Myhre, G., Shindell, D., Bréon, F.-M., Collins, W., Fuglestvedt, J., Huang, J., Koch, D., Lamarque, J.-F., Lee, D., Mendoza, B., Nakajima, T., Robock, A., Stephens, G., Takemura, T., and Zhang, H.: Anthropogenic and Natural Radiative Forcing, in: Climate Change 2013: The Physical Science Basis. Contribution of Working Group I to the Fifth Assessment Report of the Intergovernmental Panel on Climate Change, edited by: Stocker, T. F., Qin, D., Plattner, G.-K., Tignor, M., Allen, S. K., Boschung, J., Nauels, A., Xia, Y., Bex, V., and Midgley, P. M., Cambridge University Press, Cambridge, United Kingdom and New York, NY, USA, 2013.
Ram, K., Sarin, M. M., and Tripathi, S. N.: A 1 year record of carbonaceous aerosols from an urban site in the Indo-Gangetic Plain: Characterization, sources, and temporal variability, J. Geophys. Res., 115, D24313, doi:10.1029/2010JD014188, 2010.

Schuster, G. L., Dubovik, O., Holben, B. N., and Clothiaux, E. E.: Inferring black carbon content and specific absorption from Aerosol Robotic Network (AERONET) aerosol retrievals, J. Geophys. Res., 110, D10S17, doi:10.1029/2004JD004548, 2005.

Schuster, G. L., Dubovik, O., and Arola, A.: Remote sensing of soot carbon - Part 1: Distinguishing different absorbing aerosol species, Atmos. Chem. Phys. Discuss., 15, 13607-13656, doi:10.5194/acpd-15-13607-2015, 2015a.

Schuster, G. L., Dubovik, O., Arola, A., Eck, T. F., and Holben, B. N.: Remote sensing of soot carbon - Part 2: Understanding the absorption Angstrom exponent, Atmos. Chem. Phys. Discuss., 15, 20911-20956, doi:10.5194/acpd-15-20911-2015, 2015 b.

Vadrevu, K. and Lasko, K.: Fire regimes and potential bioenergy loss from agricultural lands in the Indo-Gangetic Plains, J. Environ. Manage., 148, 10-20, doi:10.1016/j.jenvman.2013.12.026, 2015.

Zhang, Q., Jimenez, J. L., Canagaratna, M. R., Allan, J. D., Coe, H., Ulbrich, I., Alfarra, M. R., Takami, A., Middlebrook, A M., Sun, Y. L., Dzepina, K., Dunlea, E., Docherty, K., DeCarlo, P. F., Salcedo, D., Onasch, T., Jayne, J. T., Miyoshi, T., Shimono, A., Hatakeyama, S., Takegawa, N., Kondo, Y., Schneider, J., Drewnick, F., Borrmann, S., Weimer, S., Demerjian, K., Williams, P., Bower, K., Bahreini, R., Cottrell, L., Griffin, R. J., Rautiainen, J., Sun, J. Y., Zhang, Y. M., and Worsnop, D. R.: Ubiquity and dominance of oxygenated species in organic aerosols in anthropogenically-influenced Northern Hemisphere midlatitudes, Geophys. Res. Lett., 34, L13801, doi:10.1029/2007GL029979, 2007. 